\title{
ROLE ASSESSMENT OF BAT EXCRETIONS IN DEGRADATION OF PAINTED SURFACE FROM MOHAMED ALI'S PALACE, SUEZ, EGYPT
}

\author{
Bakr, A. ${ }^{1} \&$ Abd El Hafez, M. ${ }^{2}$ \\ ${ }^{I}$ Asses. Prof. Conservation dept., Faculty of Archaeology, Cairo Univ., Giza, Egypt \\ ${ }^{2}$ Asses. Lecture Conservation dept., Faculty of Archaeology, Cairo Univ., Giza, Egypt
}

E-mail: amanymbakr@ hotmail.com

Received 8/2/201-

Accepted 22/6/2013

\begin{abstract}
This study discusses the assessment of the role of bats excretions (guano, blood and urine) in physiochemical degradation of historical stone surfaces for conservation purposes. The study was applied on the wall painting from Mohamed Ali palace (1812) located in Suez, Egypt. Certain parts of the inside walls of the palace suffer from the accumulation of bats excretions that lead to deformation, exfoliation and detachment of a large area of the paintings. The assessment was performed through characterization of the degradation products and the microbial activities. The study was carried out using various analytical methods such as optical microscope, scanning electron microscopy equipped with the energy dispersive X-ray (SEM$E D X)$ system and X-ray diffraction (XRD). These complementary analytical techniques allowed the identification of the wall painting components and the degradation products accumulated on the wall painting surface. The data showed the presence of phosphates minerals: Brushite $\left(\mathrm{CaHPO}_{4} \cdot 2 \mathrm{H}_{2} \mathrm{O}\right)$, Whitlockite (Ca, $\left.(\mathrm{Mg}, \mathrm{Fe})\left[\mathrm{PO}_{3} \mathrm{OH} /\left(\mathrm{PO}_{4}\right)_{6}\right]\right)$ and Newberyite $\left.\mathrm{MgHPO}_{4} \cdot 3 \mathrm{H}_{2} \mathrm{O}\right)$. These minerals are most probably derived from bat guano (excrements). The microbiological study of accumulation excretions allowed the identification of some fungi such as: Aspergillus niger, Aspergillus flavus, Acremonium cerealis, Morterilla subtilssina and one kind of Gram+ve bacillus sp. (mono-dibble-strepto bacillus). Their metabolic activities play an important role in the physiochemical disruption of paint layers.
\end{abstract}

Keywords: Bat excretions, Physiochemical degradation, Fungi, Bacteria, SEM-EDX, XRD

\section{Introduction}

Our cultural heritage represents a widely diversified group of ecological niches for various organisms since it is made from natural materials to produce several types of artifacts from very simple mono-components to complex structures integrating inorganic and organic matters. Architectural heritage, which represents an important part of this heritage, is particularly susceptible to a complex series of weathering and decay process [1] [2] [3]. In addition to physical and chemical factors, biological agents (Macroorganisms and Microorganisms) play an important role in the deterioration of cultural heritage causing aesthetic, biogeophysical and bio-geochemical damages. Biodeterioration can be defined as "any undesirable change in the properties of a material caused by the vital activities of living organisms", as distinguished from changes produced by "chemical, mechanical, and physical influences" [4]. Living organisms dwelling on the 
historical building materials and causing deterioration range from microorganisms (fungi, bacteria and alga) to macroorganisms (insects, birds, plants and animals). Numerous studies emphasize the essential role of biological agents in the stone deterioration [5]. These studies focus mainly on the role of microorganisms in stone deterioration [6] [7] [8] [9]. The role of macroorganisms in the stone deterioration is briefly mentioned in some studies [10] [11] [12] although they have an essential role in the existence of microorganisms on the stone surfaces. The excretions of some macroorganisms, which cause a remarkable amount of aesthetical and chemical damage, can provide a good growth medium for Chemoorganotrophic microorganisms which, in turn, will cause a corrosive action on materials by releasing acid metabolites [13]. Among the macroorganisms, bats have critical importance in stone deterioration since they have more destructive tools than the others. The monumental buildings are considered very suitable habitat for bats

\subsection{Site description}

Samples for the study were taken from the dome room in Mohamed Ali's palace in Suez, Egypt, fig (1-a). Mohamed Ali pasha (the establisher of the Alawi Royal family in Egypt in 1805) built the palace in 1812 during his supervision on the building of first naval arsenal in Egypt. The palace was built directly on the sea area of the Greek Street and it is considered one of the oldest buildings belonging to Mohamed Ali's reign. It was the main place that Mohamed Ali used during his planning and supervision on the Egyptian campaign to Sudan and the Hejaz. The palace consists of many rooms and halls; and its walls are decorated with amazing paintings. The dome room is the prominent part of the palace that was designed in Turkish style and decorated with floral ornaments in various colures. The palace witnessed great events of Egyptian history such as the residence of since they can use roosting niches that are indoors, semi-enclosed, partially sheltered and open structural areas. Once they enter the buildings, they can damage the building materials through their excretions. These excretions which contain guano, blood and urine not only cause aesthetic damages but also cause physicochemical changes of the substrate that lead to irreversible loss of valuable historical stone surfaces. The aim of this work is the assessment of the profound role of bats and their excretions in the deterioration of stone structures. The comprehensive information about this role will be obtained through the field evaluation of the aesthetic degradation and biodeterioration of stone structures in a historical site inhabited with bats. Degradation products including salt formation and dirt accumulation were characterized. In addition, the growth of bacteria and fungi that accompany the bats excretions was determined. This study may provide useful indications and suggestions on the best restorative and preserving strategies.

Empress Eugenie during her attendance the Suez Canal opening ceremony and watching the first performance of Opera Aida. During the rule of Mohamed Ali's family, a part of the palace was allocated to establish the second oldest religious court in Egypt during the Ottoman rule and it was opened in 1868. After the revolution of 1952, the palace was used by the governments as division of Suez security until 1980. Since that time the palace was abandoned and it became in very bad preservation state showing typical damages caused by humane gross negligence. Companioning of humane and environmental factors played an important role in destroying many of palace's architectural and ornamental elements, fig (1-b). Many parts of palace were inhabited with bats, most of them settled in the palace's dome, fig (1-c), since it is suitable structure for them. The large numbers of bats hanging from the 
dome ceiling produce great amount of droppings (feaces) and urine which make this area very odiferous. Large areas of the painting layer are very fragile and they are completely detached from the background wood constructions of the dome. Most the remains of the paintings were obliterated under the bats droppings.
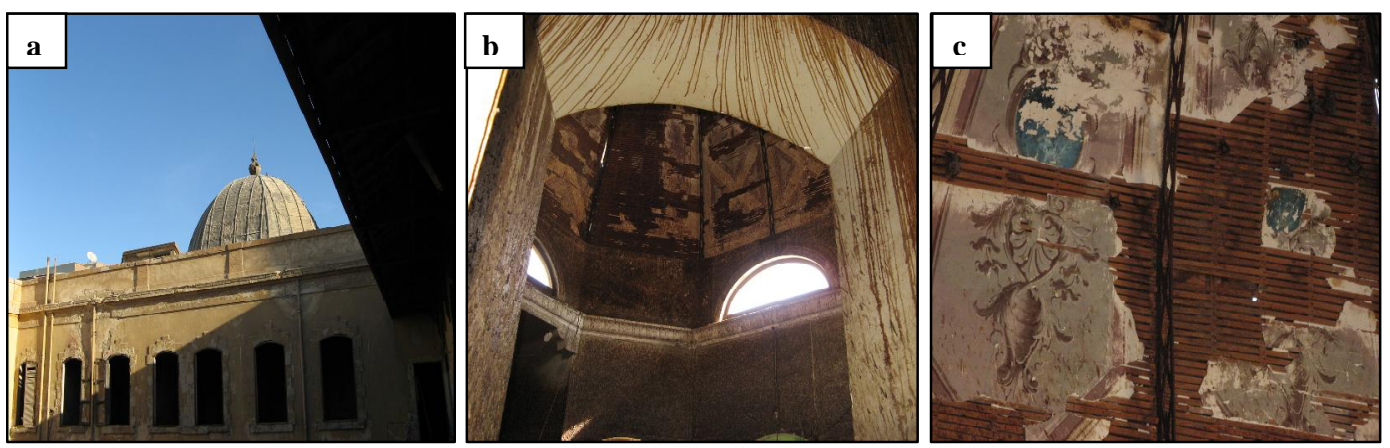

Figure (1) $\underline{\mathbf{a}}$ the dome of Mohamed Ali's palace from outside, $\underline{\mathbf{b}}$ the inside of the dome room, $\underline{\mathbf{c}}$ details from the wall paintings decorated the ceiling of the dome (some bats are seen in the picture)

\section{Materials and Methods}

\subsection{Sampling}

Several representative samples of intact painting layer containing bats droppings (guano), urine and dry blood were collected from the floor of the dome room where the pieces of painting fell down. Parts of these samples were used

\subsection{Microbiology studies procedures}

For microbiology studies the samples were cultivated on three different media: Dox's agar media, modified Dox's agar and nutrient agar media. After 10 days from incubation at 25-30c the microorganisms (fungi and bacteria) developed. Each media showed the growth of different kinds of Fungi and bacteria. The developed

\subsection{Microbiology studies procedures}

For microbiology studies the samples were cultivated on three different media: Dox's agar media, modified Dox's agar and nutrient agar media. After 10 days from incubation at $25-30{ }^{\circ} \mathrm{C}$ the microorganisms (fungi and bacteria) developed. Each media showed the growth of different kinds of Fungi and bacteria. The developed

for cultivation to determine the fungi and bacteria grown on it. The other samples were used for various analysis and examination procedures to characterize the deterioration products.

fungi and bacteria were isolated and purified. The pure cultures of each fungal and bacterial isolate were identified. The cultivation, purifying and identification were performed by the microbiology laboratory of Center of Conservation Research, Ministry of Antiquity, Cairo, Egypt.

fungi and bacteria were isolated and purified. The pure cultures of each fungal and bacterial isolate were identified. The cultivation, purifying and identification were performed by the microbiology laboratory of Center of Conservation Research, Ministry of Antiquity, Cairo, Egypt.

\subsection{Examination and analytical methods}

Some samples of intact painting layer containing bats droppings (guano), urine and dry blood were collected from different zones. These samples were 
studied, examined and analyzed to identify the different biodeterioration forms, their products and weathering state affecting the palace such as accumulated droppings, salt profiles and salt types as reported previously by ElGohary, 2010, in similar case [14]. All of these features were achieved through the following steps: * Digital optical light microscopy (OLM) attached with the computer, model (Nikon Eclipse E 800) was preliminary used to observe and detect microorganisms. * JEOL JSM S400LV EDX Lin 1 ISIS-Oxford "high vacuum", ZAF quantitative method equipped with EDX micro-analytical system was used for studying the morphology of the different bats execrations accumulated on the painted surface, in addition to quantify and qualify its elemental composition. * XRD analysis using instrumental model (Philips-PW 3071 with CuK $\alpha 40$ kV, 30 $\mathrm{mA} /$ scanned $2 \theta$ range was 5 to 60 ) was used to qualify the mineralogical composition of two samples of the intact painting layer containing bats droppings (guano), urine and dry blood

\section{Results}

\subsection{General and deterioration features by (OLM)}

The preliminary observation of the collected samples by (OLM) revealed that the yellowish surfaces of the painting within dark brown stains are observed. It was difficult to distinguish the original color of the surface under the accumulated stains.

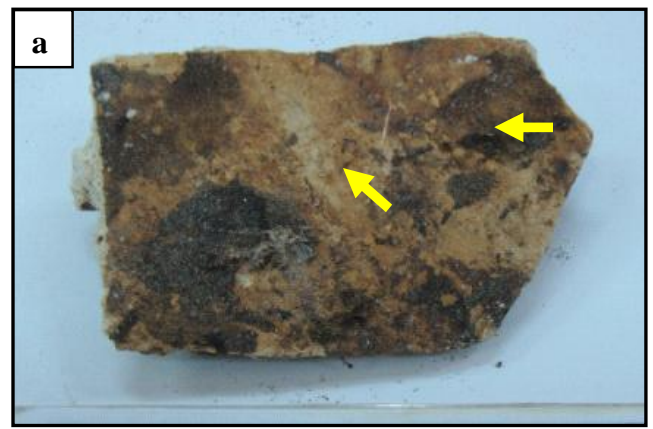

Under this layer, the main background white layer can be seen. The thickness of this layer ranges from $10 \mathrm{~mm}$ to 15 mm. large amounts of bats guano accumulated directly on the back side of this layer, all of these features are shown in, fig $(2-a, b)$.

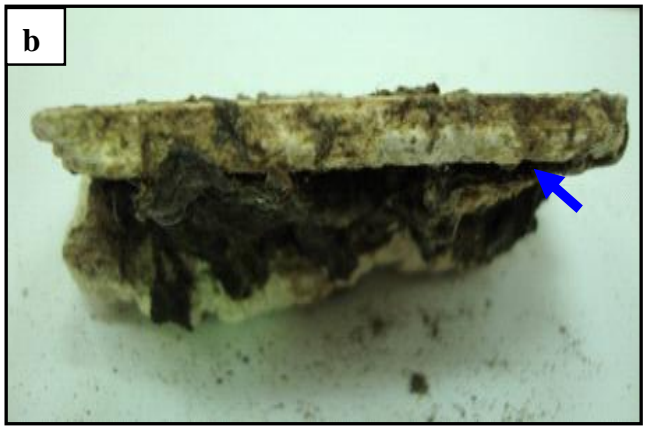

Figure (2) $\underline{\mathbf{a}} \& \underline{\mathbf{b}}$ the studied samples contains different deterioration form

\subsection{Characterization of deteriorated painted surface and related products}

\subsubsection{SEM \& EDX analytical results}

SEM-EDX examination was undertaken of the yellowish surface of the painting containing dark brown stains. The SEM observation of the dark brown stain reveals a polymeric like morphology within which are dispersed spherical coarse grains, fig. (3-a \& b). The main elemental composition of these stains are listed in tab. (1), where, the total EDX analysis showed that silicon ( $\mathrm{Si}$ ), calcium (Ca) and aluminum (Al) are the dominant elements in the sample. Significant amounts of sulphur (S), potassium $(\mathrm{K})$ and magnesium $(\mathrm{Mg})$ were recorded. Sodium $(\mathrm{Na})$, chlorine $(\mathrm{Cl})$, Copper $(\mathrm{Cu})$, Zinc $(\mathrm{Zn})$, phosphor $(\mathrm{P})$ and iron $(\mathrm{Fe})$ represent the minor elements in the sample. The morphological observation and the elemental composition of this stain indicate the presence of some salts that are related to normal chemical composition of the blood with accumulated dust particles. Moreover, the SEM observation of the yellow surface after removing the dark stain reveals the disintegrated smooth surface within which are dispersed aggregates of columnar and flaky 
crystals. EDX analysis of this sample showed that $\mathrm{S}, \mathrm{Cl}, \mathrm{Ca}, \mathrm{Si}$ and $\mathrm{K}$ are the major elements in the studied area. Considerable amounts of $\mathrm{Na}, \mathrm{P}, \mathrm{Al}$ and $\mathrm{Mg}$ were recorded. The observed crystal features and the elemental composition suggested it is a mixture of gypsum and various kinds of potassium, chlorine and phosphate salts. Furthermore, SEM-EDX, examination results of the undertaken surface layer contacted directly with bat guano showed interesting morphologies.
The surface reveals a generally coarse morphology with presence of parts of undigested insects and bats hairs, fig (3c). The EDX microanalysis of this layer listed in tab. (1) showed that $\mathrm{Ca}, \mathrm{S}, \mathrm{Si}$, $\mathrm{Na}, \mathrm{K}$ and $\mathrm{P}$ are the major elements in the sample. Considerable amounts of $\mathrm{Cl}$ and $\mathrm{Mg}$ were also recorded. The significant detected amounts of $\mathrm{P}$ and $\mathrm{K}$ in this sample are probably related to the direct contact of this layer with bat guano.
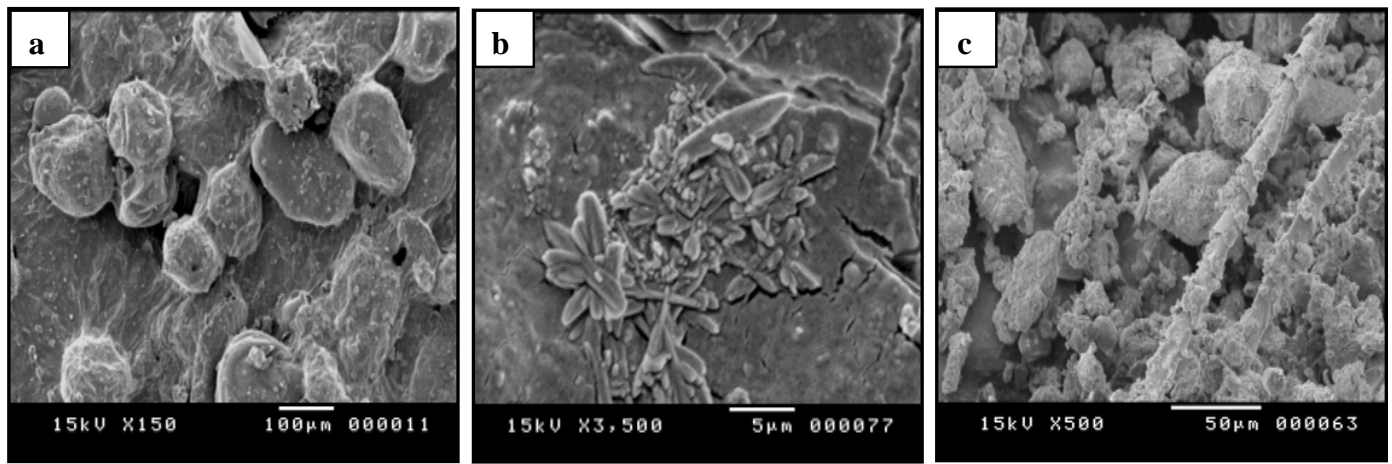

Figure (3) $\underline{\mathbf{a}}, \underline{\mathbf{b}} \& \underline{\mathbf{c}}$ SEM images of the selected areas from the studied samples

Table 1: SEM-EDX microanalysis of the studies samples

\begin{tabular}{|c|c|c|c|}
\hline $\begin{array}{c}\text { Elements } \\
(\%)\end{array}$ & Dark brown stain & $\begin{array}{c}\text { Yellow surface } \\
\text { under the dark stain }\end{array}$ & Rough cross section \\
\hline $\mathbf{N a}$ & $03.96-5.92$ & $04.22-8.63$ & $09.37-9.78$ \\
\hline $\mathbf{M g}$ & $05.42-7.00$ & $03.24-4.13$ & $02.75-3.31$ \\
\hline $\mathbf{A l}$ & $10.0-11.57$ & $03.48-4.42$ & $06.68-6.71$ \\
\hline $\mathbf{S i}$ & $29.2-31.76$ & $9.11-10.19$ & $21.60-21.72$ \\
\hline $\mathbf{P}$ & $02.03-2.45$ & $02.02-3.31$ & $04.64-4.87$ \\
\hline $\mathbf{S}$ & $07.34-7.99$ & $17.02-32.2$ & $13.9-13.23$ \\
\hline $\mathbf{C l}$ & $04.08-5.27$ & $14.4-16.47$ & $06.35-7.42$ \\
\hline $\mathbf{K}$ & $07.68-9.91$ & $07.78-8.81$ & $08.51-9.35$ \\
\hline $\mathbf{C a}$ & $10.85-15.0$ & $12.18-14.0$ & $19.71-20.03$ \\
\hline $\mathbf{F e}$ & $02.36-2.60$ & $01.14-1.43$ & $01.44-2.27$ \\
\hline $\mathbf{C u}$ & $02.97-5.44$ & $01.97-2.24$ & $01.31-2.71$ \\
\hline $\mathbf{Z n}$ & $02.46-4.34$ & $00.53-0.82$ & $00.86-1.65$ \\
\hline
\end{tabular}

\subsubsection{XRD analytical results}

As shown in fig. (4), XRD analysis of the yellowish painting layer in direct contact with bat guano showed the presence of gypsum $\left(\mathrm{CaSO}_{4} \cdot 2 \mathrm{H}_{2} \mathrm{O}\right)$ as a main component. Smaller amount of calcite $\left(\mathrm{CaCO}_{3}\right)$ and quartz $\left(\mathrm{SiO}_{2}\right)$ were also detected. These minerals most probably represent in the main compositions of the painted layer. Small amount of halite $(\mathrm{NaCl})$, clay minerals (Kaolinite and Montmrillonite) were recorded, and finally some phosphate minerals are detected, they are:

- Brushite $\left(\mathrm{CaH}\left(\mathrm{PO}_{4}\right) .2 \mathrm{H} 2 \mathrm{O}\right)$

- Newberyite $\mathrm{MgHPO}_{4} \cdot 3 \mathrm{H}_{2} \mathrm{O}$ )

- Whitlockite $\left(\mathrm{Ca}_{9}(\mathrm{Mg}, \mathrm{Fe})\left[\mathrm{PO}_{3} \mathrm{OH} /\left(\mathrm{PO}_{4}\right)_{6}\right]\right)$ 


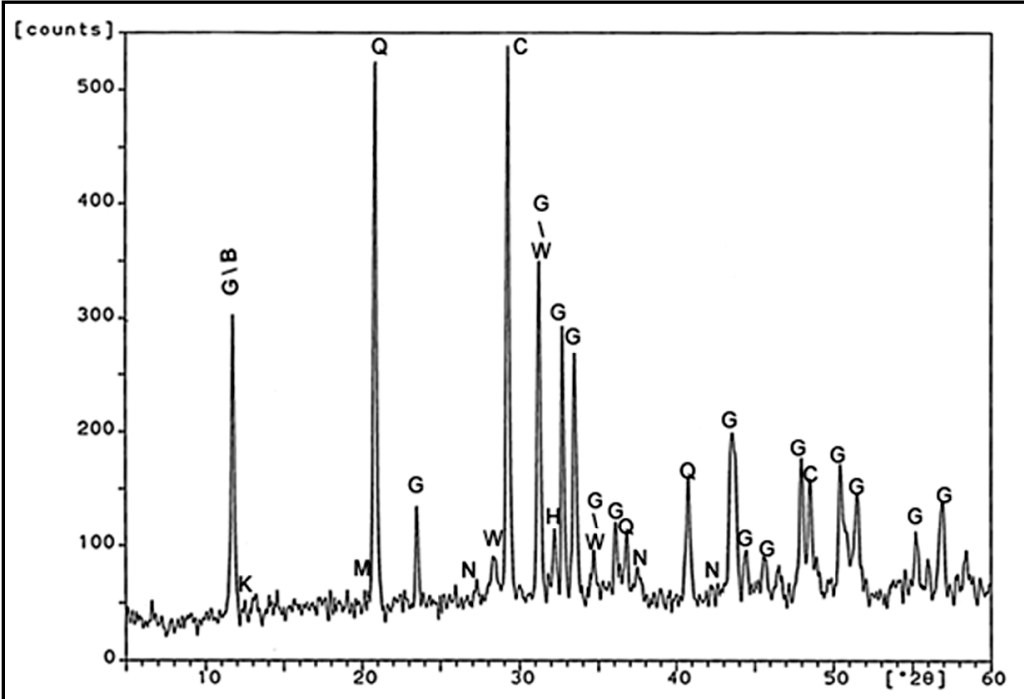

Figure (4) XRD patterns of the studied sample. $\mathrm{G}=$ gypsum, $\mathrm{B}=$ brushite, $\mathrm{Q}=$ quartz, $\mathrm{N}=$ newberyite, $\mathrm{W}=$ whitlockite, $\mathrm{K}=$ kaolinite, $\mathrm{M}=$ montmrillonite and $\mathrm{H}=$ halite

\subsection{Microbial activities of the studied samples}

Cultures of the studied samples show a good growth of microorganisms mass. The OLM examination showed the presence of four kinds of fungi and one kind of bacteria. Aspergillus niger, Aspergillus flavus and Acremonium cerealis grew on the Dox's agar media while Morterilla subtilssina grew on modified Dox's agar. G+ve Bacillus sp. (Mono-Dibble- strepto bacillus) grew on nutrient agar media, fig. (5-a, b, c, d). Actually, by using the current types of culture media, we were able to cultivate only a small part of the whole microbial population.
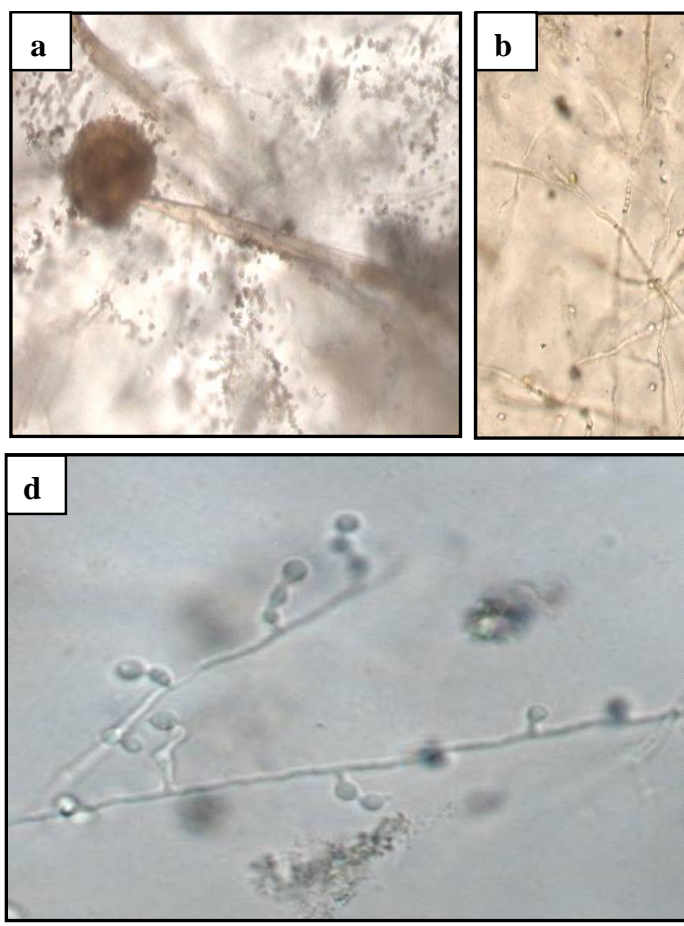
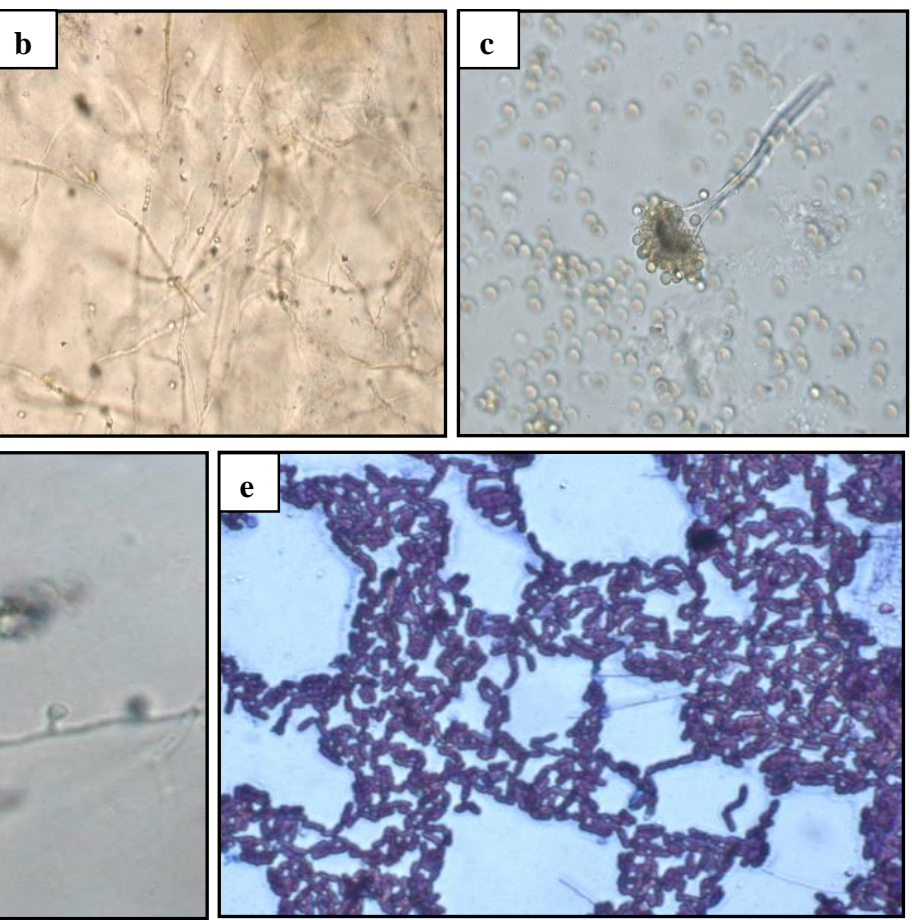

Figure (4) microphotographs of isolated fungi and bacteria, (a) Aspergillus niger, (b) Acremonium cerealis, (c) Aspergillus flavus (d) Morterilla subtilssina, (e) G+ve Bacillus sp. (MonoDibble- strepto bacillus). 


\section{Discussion}

SEM-EDX and XRD results of the painted surface showed that gypsum $\left(\mathrm{CaSO}_{4} \cdot 2 \mathrm{H}_{2} \mathrm{O}\right)$ is the main component of this layer with smaller amounts of calcite $\left(\mathrm{CaCo}_{3}\right)$ and quartz $\left(\mathrm{SiO}_{2}\right)$. The surface morphology, the observed crystal features and the elemental composition $(\mathrm{Ca}, \mathrm{S}, \mathrm{Si}, \mathrm{Na}, \mathrm{K}, \mathrm{P}, \mathrm{Cl}$ and $\mathrm{Mg}$ ) of the studied samples indicate the presence of some salts that most probably related to the normal chemical composition of the blood and bat guano accumulated on the painted surface. Furthermore, XRD analysis indicate the presence of Halite $(\mathrm{NaCl})$ and Phosphate minerals such as Brushite $\left(\mathrm{Ca} \mathrm{H}\left(\mathrm{PO}_{4}\right) .2 \mathrm{H}_{2} \mathrm{O}\right)$, Whitlockite $\left(\mathrm{Ca}_{9}\right.$ $\left.(\mathrm{Mg}, \mathrm{Fe}) \quad\left[\mathrm{PO} \mathrm{OH}_{3} /\left(\mathrm{PO}_{4}\right)_{6}\right]\right)$ and Newberyite $\left.\mathrm{MgHPO}_{4} \cdot 3 \mathrm{H}_{2} \mathrm{O}\right)$. The phosphates salts detected in the sample are related to bat guano accumulated on the painted surface. The companioning of phosphate and sulfates minerals with the presence of bats guano was mentioned in many studies of the stone deterioration by salt efflorescence [15] [16] [17] [18]. Bat guano consists mostly of excrement with undigested part of insects and it contains significant amounts of phosphor, potassium and nitrogen. It is also rich in a wide range of elements such as sulphur, calcium, sodium, zinc, iron, and magnesium [19]. The organic compounds in the excrement containing sulphur, phosphorous and nitrogen may form sulphuric, phosphoric and nitric acids after decomposition and oxidation. These acids react with base elements in the substrata on which it deposit to form their corresponding salts, sulphates, phosphates and nitrates. Potassium and nitrates compounds could not be detected in many cases because of their soluble properties. In our case, no potassium mineral was detected although potassium element was recorded in the EDX analysis.
Within the same context, the complex chemical composition of the studied samples containing bats droppings (guano), urine and dry blood indicate that a wide spectrum of microorganisms should be present. Steele, D. [20] reported that the chemical analysis of bat guano is quite similar to an elemental analysis of the manufactured bacteriological growth media used in microbiology laboratories throughout the world. In recent years some studies concerned with the environment of batinhabited caves reveals the presence of a wide range of microbial activities that is related to the presence of bat guano [21] [22] [23]. Aspergillus sp. and Acremonium sp. had a casual distribution on the archaeological stone surface and wall paintings under various suitable conditions [24] [25]. The presence of Morterilla sp. was always associated with bat guano [26]. The ability of these organisms to cause serious damage to many kinds of stone structures has been well established [27] [28]. It was estimated that biological weathering is $100-1000$ times greater than inorganic weathering [6]. The accumulation of bat guano on the historical stone structures create very encouraging conditions for millions of micro-organisms (bacteria, fungi and actinomycetes) which decompose the organic matter, transforming it into different organic acids, enzymes, antibiotics and other organic compounds. This decomposition process means that bat guano is acidic all the time. In our case, the $\mathrm{pH}$ measurement of the yellowish painting layer contacted directly with bat guano revealed the $\mathrm{pH}$ value ranging from 4 to 4.6. Figure (5) confirming the acidification of the accumulated bat guano on the painting layer. The acidic attack of the stone structure is one of the main mechanisms of biodeterioration. In addition to the acidity effect of bat 
guano, bat urine (which is about $70 \%$ urea) has very strong alkaline effect and it can cause pitting, staining or etching of painted surfaces. The results of this study showed that the bat

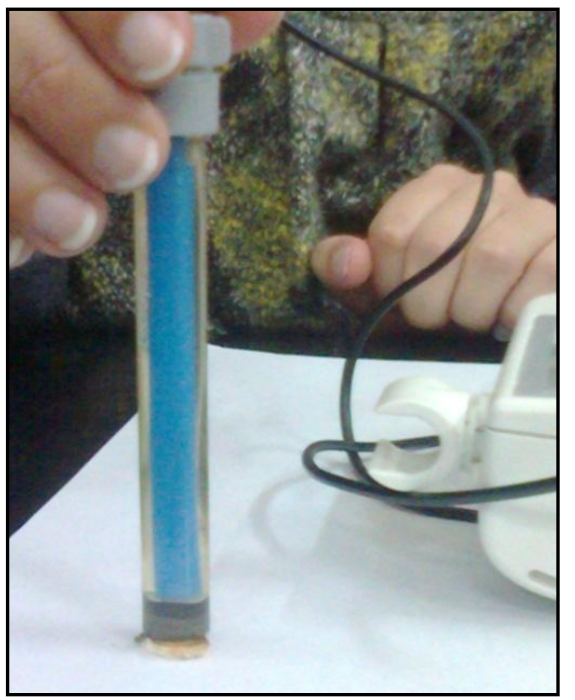

Figure (5) $\mathrm{pH}$ measurement of the studied samples excretions have very strong combined decay tools which can achieve the two types of biodeterioration: biogeophysical and biogeochemical deterioration of stone structure [29] [30].

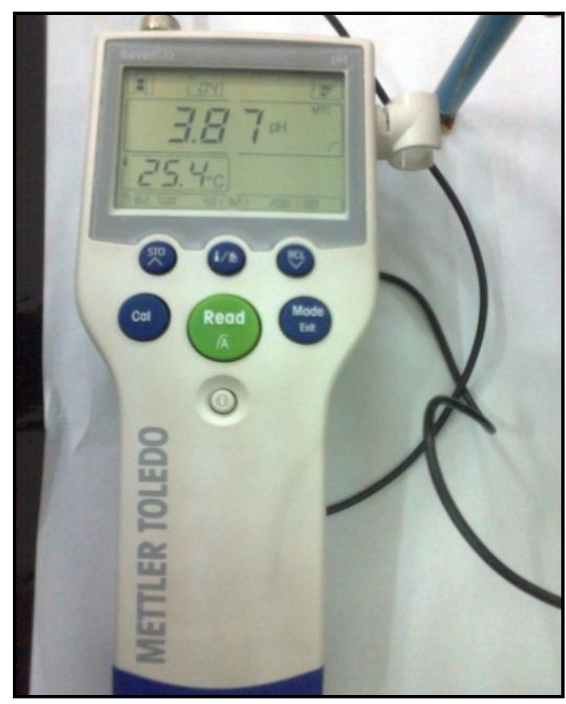

\section{Conclusion}

Samples collected from Mohamed Ali palace, which is inhabited with bats, were studied in order to evaluate the role of bat excretions in the deterioration of the painted surface. The surface examination and the elemental analysis by SEM-EDX showed the very complex surface morphology with very characteristic elemental compositions that represented the diversity of accumulated bat excretions (guano and blood). The mineral analysis by XRD reveals the presence of phosphate salts that originated from accumulated guano such as Brushite $\left(\mathrm{CaHPO}_{4} \cdot 2 \mathrm{H}_{2} \mathrm{O}\right)$, Whitlockite $\left(\mathrm{Ca},(\mathrm{Mg}, \mathrm{Fe})\left[\mathrm{PO}_{3} \mathrm{OH} /\left(\mathrm{PO}_{4}\right)_{6}\right]\right)$ and Newberyite $\left.\mathrm{MgHPO}_{4} \cdot 3 \mathrm{H}_{2} \mathrm{O}\right)$. The microbiology studies allow us to identify the main microorganisms that colonize the painted surfaces containing bat droppings. The identified bacteria and fungi play an important role in the biodeterioration process through a bio-solubilization mechanism involving the production of metabolic acids that. The results of this study emphasized that bat excretions contribute significantly in the deterioration of cultural heritage causing aesthetic, biogeophysical and biogeochemical damages, and thus the protection of the palace from bat should be carried out immediately

\section{Acknowledgment}

The authors wish to thank Dr. Atif Abdel kawi, Dr. Ali Omer, Dr. Dalia Ahmed, Rehan Adel and Ghada Darwish from Center of conservation and research, Ministry of Antiquities, Egypt, for the isolation and identification of microorganisms

\section{References}

[1] Honeyborne, D., (1998). Weathering and decay of masonry, in: Ashurst, J. \& Dimes, F. (eds.) Conservation of Building and Decorative Stone, Butterworth, Heinemann, Oxford, pp: 153-178.

[2] Feilden, B., (2003). Conservation of historic buildings. $3^{\text {rd }}$ ed. Architectural Press, Oxford.
[3] Smith, B., Gomez-Heras M., \& McCabe., S., (2008). Understanding the decay of stone-built cultural heritage, Progress in Physical Geography 32 (4), pp: 439-461.

[4] Kumar, R. \& Kumar, A., (1999). Biodeterioration of stone in tropical environments: An overview, The Getty Conservation Institute, Malibu, USA. 
[5] Warscheid, Th. \& Braams, J., (2000). Biodeterioration of stone: a review, Int. Biodeterioration \& Biodegradation, Vol. 46 (4), pp: 343-368.

[6] Aghamiri, R., \& Schwartzman D., (2002). Weathering rates of bedrock by lichens: A mini watershed study, Chemical Geology, Vol. 188 (3-4) pp: 249-259.

[7] McNamara, Ch. \& Mitchell, R., (2008). Microbial deterioration of historic stone, Front Ecol Environ, Vol 3 (8), pp.445-451.

[8] Krumbein, W. \& Diakumaku, E., (1995). The role of fungi in the deterioration of stones, research report N2, Environment / Protection and Conservation of the European Cultural Heritage, Belgium.

[9] Mary-Lou E., (2004). Fungal facts solving fungal problems in heritage collections, Archetype Publications, London.

[10] Urzì C., Krumbein W. E. (1994). Microbiological impacts on the cultural heritage, in: Krumbein W., Brimblecombe P., Cosgrove D. \& Staniforth S. (eds.). Durability and change: the science, responsibility, and cost of sustaining cultural heritage, Wiley, J. \& Sons. pp: 107135.

[11] Keopannha, V., (2008). Museum collections and biodeterioration in Laos, MA Thesis, International Museum studies Museion, Gothenburg Univ.

[12] Pinniger, D., (2001). Pest management in museums, Archives and historic houses, Archetype Publications, London.

[13] Bassi, M. \& Chiatante, D., (1976). The role of pigeons excrement in the stone deterioration. Int. Biodeterioration, Vol. 12, pp: 73-79.

[14] El-Gohary, M., (2010). Investigation on limestone weathering of El-Tuba minaret El-Mehalla, Egypt: a case study, MAA, Vol. 10 (1), pp: 61-79.

[15] Uchida E., Ogawa Y, Maeda N. \& Nakagawa T., (1999). Deterioration of stone materials in the Angkor monuments, Cambodia, Engineering Geology, Vol. 55 (1-2) pp: 101-112.

[16] Siedel, H., Plehwe-Leisen, E. \& Leisen, H., (2008). Salt load and deterioration of sandstone at the temple of Angkor wat, Cambodia, in: Łukaszewicz, J. \& Niemcewicz, P. (eds.) $11^{\text {th }}$ Int. Cong. on Deterioration and Conservation of Stone, Vol. I, Torun, Poland, pp: 267-274

[17] Hosono T., Uchida E., Suda C., Ueno A. \& Nakagawa T., (2006), Salt weathering of sandstone at the Angkor monuments, Cambodia: identification of the origins of salts using sulfur and strontium isotopes. Archaeological Science, Vol. 33 (11) pp: 1541-1551.

[18] Doehne, E., (2003). Salt weathering: A selective review, Geological Society Special Publication: Natural Stone, Weathering Phenomena, Conservation Strategies and Case Studies. Vol. 205, pp: 51-64.

[19] Mlay, P., \& Sagamiko, F. (2008). The use of bat guano in the improvement of the nutritive value of poor quality roughage fed to ruminants in Tanzania, Veterinarski Arhiv, Vol. 78 (5), pp: 417-427,

[20] Bernie, S., (1989). Bats, Bacteria and Biotechnology, Bats Magazine, Vol. 7 (1), pp: 1 - 3.

[21] Urzì, C., De Leo, F., Bruno, L. \& Albertano, P., (2010). Microbial diversity in Paleolithic caves: A study case on the phototrophic biofilms of the cave of bats (Zuheros, Spain), Microb Ecol., Vol. 60 (1) pp: 116-129,

[22] Sugita, T., Kikuchi, K., Makimura, K., Urata, K., Someya, T., Kamei, K., Niimi, M. \& Uehara, Y., (2005). Trichosporon species isolated from guano samples obtained from batinhabited caves in Japan. Appl Environ Microbiol, Vol. 71 (11), pp: 7626-7629

[23] Jurado, V., Laiz, L., Rodriguez-Nava, V., Boiron, P., Hermosin, B., Sanchez-Moral, S. \& Saiz-Jimenez, C., (2010). Pathogenic and 
opportunistic microorganisms in caves, Int. Journal of Speleology, Vol. 39 (1) pp: 15-24.

[24] Garg, K., Kamal, K. \& Mishra, A., (1995). Role of fungi in the deterioration of wall paintings, The Science of the Total Environment, Vol. 167, pp: 255-271.

[25] Sharma K. \& Lanjewar, S., (2010). Biodeterioration of ancient monument (Devarbija) of Chhattisgarh by Fungi, J. Phytology Microbiology, Vol. 2 (11), pp: 47-49.

[26] Yousuke D. \& Walter, G., (2004). A new species of Mortierella, and an associated sporangiiferous mycoparasite in a new genus, Nothadelphia, Studies in mycology, Vol. 50, pp: 567-572.

[27] Euan P., Martin, K. \& Gadd, G., (2003). Geomycology: fungi in mineral substrata, Mycologist, Vol. 17 (3), Cambridge University Press, pp: 98-107.
[28] Bakr, A. \& Mansour, M., (2010).The role of inappropriate outdoor exhibition in the biodeterioration of an archaeological limestone water duct, in: Radwan, A \& El-Kahlawy, M., (eds.) $13^{\text {th }}$ Conference for the association of the Arab archaeologists, Cairo, Egypt, pp: 1-21

[29] Macedo, M., Miller, A., Dionı'sio, A. \& Saiz-Jimenez, C., (2009). Biodiversity of cyanobacteria and green algae on monuments in the Mediterranean Basin: An overview, Microbiology, Vol. 155, pp: 34763490.

[30] Saiz-Jimenez, C., (1997). Biodeterioration $v s$ Biodegradation: the role of microorganisms in the removal of pollutants deposited on historic buildings, Int. Biodeterioration and Biodegradation, Vol. 40 (2-4), pp. 225-232 